\title{
PENGARUH KREATIVITAS GURU TERHADAP HASIL BELAJAR SISWA PADA MATA PELAJARAN EKONOMI DI SMA NEGERI 1 MOUTONG KABUPATEN PARIGI MOUTONG PROVINSI SULAWESI TENGAH
}

\author{
Mariane Umar \\ STIA Bina Taruna Gorontalo \\ marianeumar902@gmail.com
}

\begin{abstract}
ABSTRAK
Tujuan penelitian ini adalah untuk mengetahui seberapa besar pengaruh kreativitas guru terhadap hasil belajar siswa pada mata pelajaran ekonomi di SMA Negeri 1 Moutong Kabupaten Parigi Moutong Provinsi Sulawesi Tengah. Penelitian ini adalah penelitian korelasi dengan menggunakan teknik stratified random sampling. Instrumen dalam penelitian ini adalah tes kreativitas guru dan tes hasil belajar siswa. Populasi dalam penelitian ini berjumlah 122 siswa, untuk kepentingan uji coba instrumen dilakukan kepada 30 siswa dan untuk kepentingan pengumpulan data primer ditetapkan sampel sebanyak 92 Siswa. Hasil penelitian menemukan terdapat pengaruh kreativitas guru terhadap hasil belajar siswa pada mata pelajaran ekonomi di SMA Negeri 1 Moutong Kabupaten Parigi Moutong Provinsi Sulawesi Tengah, dengan data pengaruh sebesar $32,77 \%$.
\end{abstract}

\section{Kata Kunci: Kreativitas Guru, Hasil Belajar}

\section{PENDAHULUAN}

Keberhasilan pendidikan tergantung pada mutu pendidikan yang berkualitas serta dilaksanakan dengan penuh tanggung jawab oleh seorang guru. Guru merupakan tenaga pengajar dalam menciptakan proses belajar mengajar yang dinamis, sehingga dapat menghasilkan mutu pendidikan yang berkualitas ditinjau dari segi pengetahuan maupun keterampilannya agar dapat mengembangkan potensi sesuai dengan sasaran dan tujuan dari pendidikan itu sendiri.

Tenaga pengajar merupakan salah satu penentu pendidikan, untuk itu perlu adanya pengembangan kemampuan baik dari segi ilmu pengetahuan maupun dari segi keterampilan dalam mengelola proses belajar mengajar. Guru harus terampil dan kreatif dalam meningkatkan semangat belajar siswa agar seluruh perhatian siswa dapat tertuju dan terpusat pada bahan pelajaran yang sedang diajarkan.

Guru yang baik diharapkan menjadikan dirinya sebagai tenaga pendidik yang profesional, dan untuk mendapatkan guru yang profesional merupakan suatu keharusan. Keberhasilan pendidikan sangat bergantung pada unsur manusianya, terutama guru. Oleh karena itu, kreativitas guru sangat diharapkan dalam mengajar dan mendidik para siswa. Sebab guru merupakan ujung tombak yang secara langsung dapat 
berupaya untuk mempengaruhi, memotivasi, membimbing, membina, dan mengarahkan kemampuan siswa agar menjadi manusia yang cerdas, terampil dan bermoral tinggi.

Dalam kurikulum 2004 yang berbasis kompetensi, guru terutama berperan dalam mengembangkan materi standar dan membentuk kompetensi peserta didik. Sehubungan dengan itu, guru harus kreatif, profesional, dan menyenangkan. Guru harus profesional dalam membentuk kompetensi peserta didik sesuai dengan karakteristik individual masing-masing. Guru juga harus menyenangkan, tidak saja bagi peserta didik tetapi juga bagi dirinya. Artinya belajar dan pembelajaran harus menjadi makanan pokok guru seharihari, harus dicintai, agar dapat membentuk dan membangkitkan rasa cinta dan nafsu belajar siswa dalam kondisi dan perubahan yang bagaimanapun.

Anawati (2008) proses kreatif dalam pembelajaran sangat penting bagi seorang guru. Menciptakan suasana kelas yang penuh inspirasi bagi siswa, kreatif dan antusias merupakan tugas dan tanggung jawab seorang guru. Dengan begitu waktu belajar menjadi saat yang dinantinantikan oleh siswa ke segala aspek kehidupan. Begitu pula persaingan hidup yang semakin ketat menjadi figur dan contoh kreatif bagi setiap nilai dan pencapaian kompetensi siswa adalah sebuah tantangan.

Guru sebagai tenaga pendidik memiliki kewajiban mencari, menemukan dan diharapkan mampu memecahkan masalah-masalah belajar yang dihadapi oleh siswa. Sikap dan perilaku guru merupakan modal dasar untuk mengembangkan dirinya.
Namun kurangnya usaha untuk menggali dan mengembangkan dirinya, maka dari waktu ke waktu sistem mengajar sifatnya monoton dan membosankan. Hal ini akan mengakibatkan timbulnya semacam sistem pembelajaran tradisional dimana para siswa hanya dapat menjawab segala pertanyaan yang ditujukkan oleh guru. Setiap guru perlu menyadari bahwa tidak semua mata pelajaran menarik perhatian siswa, termasuk pula mata pelajaran ekonomi. Pada kondisi seperti ini kreativitas mengajar guru mutlak diperlukan agar aktivitas mengajar dapat meningkat sesuai dengan harapan dan tujuan pendidikan.

Guru menyadari bahwa tidak setiap bahan pelajaran dapat menarik perhatian siswa dan tidak semua siswa menaruh perhatian terhadap bahan pelajaran yang sama. Dari jumlah seluruh siswa tidak semuanya tertarik pada mata pelajaran ekonomi, sehingga siswa akan merasa bosan dan jenuh ketika pelajaran sedang berlangsung yang akan menyebabkan rendahnya hasil belajar siswa. Oleh karena itu sangat diperlukan kecakapan dan kreativitas guru dalam membangkitkan semangat belajar dan perhatian siswa terhadap bahan pelajaran yang sedang diajarkan. Kreativitas guru dalam proses belajar mengajar merupakan kunci sentral guru sebagai motivator dan pendidik, dalam arti bahwa seorang guru yang kreatif diharapkan mampu menciptakan kondisi belajar sedemikian rupa, sehingga hasil belajar siswa tercapai seoptimal mungkin.

Kenyataan yang terjadi di SMA Negeri 1 Moutong, hasil belajar siswa belum kondusif. Hal ini dipengaruhi 


\begin{abstract}
oleh kreativitas guru belum sepenuhnya bisa meningkatkan hasil belajar siswa, sebab metode pembelajaran yang diterapkan masih bersifat konvensional, seperti metode ceramah, tanya jawab dan penugasan. Dalam hal ini untuk meningkatkan hasil belajar siswa pada mata pelajaran ekonomi, guru perlu juga ceramah, pemberian tugas, tetapi dibarengi dengan kreativitas untuk memilih metode, media, teknik, ataupun pendekatan pembelajaran yang disajikan.
\end{abstract}

\section{KAJIAN TEORI}

\section{Hasil Belajar}

Hasil belajar diartikan sebagai kemampuan dalam memperoleh nilai pada suatu materi setelah peserta didik melaksanakan aktivitas belajar pada waktu tertentu. Hasil belajar ini biasanya diperoleh peserta didik setelah guru melaksanakan ulangan atau menggunakan tes tertulis maupun tidak tertulis. E Mulyasa (2005:21) "hasil belajar adalah prestasi yang dihadapi, dilaksanakan oleh peserta didik". Sementara dalam pandangan Harianto (2001:30) "hasil belajar yaitu sebuah kegiatan belajar mengajar dimana hasil belajar peserta didik ditandai dengan standar nilai". Dengan demikian jelaslah bahwa hasil belajar pada hakikatnya adalah semua perolehan nilai peserta didik menjalani kegiatan belajar pada waktu tertentu untuk mengejar suatu prestasi serta mendapatkan suatu nilai.

Herward Kingsley membagi tiga

macam hasil belajar, yakni:

keterampilan dan kebiasaan, (b) pengetahuan dan pengertian, (c) sikap dan cita-cita. Hamalik (2001:159) mengatakan bahwa hasil-hasil belajar adalah keseluruhan kegiatan pengukuran (pengumpulan data dan informasi), pengeluhan, penafsiran, dan pertimbangan untuk membuat keputusan tentang tingkat hasil belajar yang dicapai oleh siswa setelah melakukan kegiatan belajar dalam upaya mencapai tujuan pembelajaran yang tetap. Menurut Sudjana (2008:22) lingkup hasil belajar yang diukur meliputi tiga kawasan yaitu: kognitif, afektif, dan psikomotorik.

Berdasarkan pendapat di atas, dapat disampaikan bahwa hasil belajar merupakan suatu perolehan nilai siswa pada materi tertentu setelah mereka mengalami aktivitas belajar dalam jangka waktu tertentu pula. Hasil belajar diperoleh masing-masing siswa, biasanya akan diketahui setelah guru melakukan penilaian dengan menggunakan tes, baik dalam bentuk pertanyaan lisan maupun tulisan. Hasil belajar juga dapat diartikan sebagai pengukuran yang ditandai dengan tingkat perolehan siswa setelah menjalani kegiatan belajar mengajar dalam upaya mencapai tujuan pembelajaran. Masing-masing ranah terdiri dari sejumlah aspek yang saling berkaitan. Oleh sebab itu, penilaian terhadap proses belajar siswa meliputi aspek kognitif, afektif, psikomotorik, dan alat untuk setiap ranah berbeda dalam cakupan dan hakikat yang terkandung di dalamnya.

\section{Kreativitas Guru}

Semiawan (dalam Hawadi 2011:4) berpendapat bahwa kreativitas merupakan kemampuan untuk memberikan gagasan-gagasan baru dan menerapkan dalam pemecahan masalah, baik dilihat dari ciri-ciri attitude: kelancaran (fluency), keluwesan (fleksibility), dan keaslian 
(originality) dalam pemikiran maupun dilihat dari ciri-ciri non-attitude: rasa ingin tahu, senang mengajukan pertanyaan, dan selalu mencari pengalaman-pengalaman baru. Faktor utama yang mempengaruhi belajar siswa adalah kreativitas guru, sebab di lingkungan sekolah guru berperan untuk meningkatkan hasil belajar siswa. Guru harus selalu berusaha membangkitkan minat siswa sehingga seluruh perhatian mereka tertuju dan terpusat pada bahan pelajaran yang sedang diajarkan.

Menurut Munandar (1992:4750) bahwa kreativitas dapat dilihat dari tiga tekanan kemampuan yaitu: (1) kemampuan untuk membuat kombinasi baru berdasarkan data dan informasi atau unsur-unsur yang ada; (2) kemampuan berdasarkan data dan informasi yang tersedia, menemukan banyak kemungkinan jawaban terhadap suatu masalah, dimana penekanannya adalah pada kuantitas ketepatgunaan dan keraguan jawaban, dan (3) kemampuan yang secara operasional mencerminkan kelancaran, keluwesan, dan orisinalitas dalam berfikir, secara kemampuan untuk mengelaborasi (mengembangkan, memperkaya, dan memperinci) suatu gagasan.

Berdasarkan pendapat beberapa ahli di atas, disimpulkan bahwa kreativitas merupakan suatu kemampuan seseorang untuk menciptakan suatu karya yang baru untuk meningkatkan semangat berlajar siswa agar siswa tidak merasa jenuh untuk mengikuti suatu proses pembelajaran. Konsep kreativitas mengacu kepada kemampuan guru dalam menentukan ataupun mengemukakan gagasan/ide baru dalam pengaturannya. Guru menyampaikan hasil yang maksimal. Ada beberapa indikator yang berpengaruh di dalam konsep kreativitas guru yakni antara lain: kemampuan menguasai bahan ajar, kemampuan mengelola kelas, dan kemampuan dalam menggunakan media.

Dalam proses belajar mengajar perlu sikap kreatif dari seorang guru, sehingga proses belajar mengajar dapat berlangsung dengan baik. Proses belajar mengajar dikatakan baik bila proses tersebut membangkitkan semangat belajar yang efektif. Hal ini seperti yang dapat dikemukakan oleh Parnes (dalam Nursisto, 1999:31) mengemukakan ada lima perilaku kreatif yang dilakukan oleh guru yaitu:

1) Fluency (kelancaran) yaitu kemampuan untuk menghasilkan gagasan dalam menyelesaikan suatu masalah, berupa: (a) kelancaran dalam menyampaikan materi yang digunakan; (b) menggunakan metode mengajar sesuai dengan keadaan siswa; (c) menggunakan peralatan pengajaran dan alat bantu lainnya sesuai dengan tujuan; dan (d) menggunakan dengan tepat bahan pelajaran sesuai dengan tujuan.

2) Fleksibility (keluwesan) yaitu kemampuan untuk menghasilkan berbagai macam ide guna memecahkan suatu masalah di luar kategori biasa, berupa: (a) menunjukkan sikap terbuka terhadap pendapat siswa; (b) menunjukkan sikap luwes baik di dalam maupun di luar kelas; (c) menerima siswa sebagaimana adanya dengan segala kelebihan dan kekurangannya; dan (d) menunjukkan sikap ramah, penuh pengertian dan sabar baik kepada 
siswa maupun teman sejawat/orang lain.

3) Originalitas (keaslian) yaitu kemampuan untuk memberikan respon yang unik atau luar biasa, berupa: (a) menunjukkan sikap kegairahan dalam mengajar; (b) merangsang dan memotivasi siswa untuk belajar; dan (c) memberikan kesan kepada siswa bahwa ia menguasai apa yang diajarkan dan cara mengajarkannya.

4) Elaboration (keterperincian) yaitu kemampuan untuk menyatakan ide secara terperinci untuk mewujudkan ide menjadi kenyataan, berupa: (a) melakukan penilaian selama proses belajar mengajar berlangsung; (b) mendemonstrasikan pelaksanaan penilaian baik dengan lisan, tulisan maupun dengan cara pengamatan; (c) menafsirkan hasil penelitian dalam proses mengajar yang telah dilaksanakan; dan (d) menggunakan prosedur penilaian dengan melibatkan siswa pada awal pengajaran.

5) Sensitivity (kepekaan) yaitu kepekaan menangkap dan menghasilkan masalah sebagai tanggapan terhadap suatu situasi, berupa: (a) menunjukkan sikap sensitif, responsif dan simpatik terhadap perasaan dan kesukaran siswa; (b) memberikan kesempatan siswa untuk berpartisipasi; dan (c) memelihara keterlibatan siswa dalam memelihara ketertiban.

Sehubungan dengan pendapat di atas maka dapat simpulkan bahwa ciri guru yang memiliki kreativitas dalam mengajar yaitu keterbukaan atas pengalaman baru, mampu mengembangkan gagasan, tidak meniru gagasan orang lain, fleksibilitas dalam berpikir dan merespon kepentingan guru berminat pada kegiatan yang kreatif, mampu menyesuaikan diri, peka terhadap lingkungan sekolah, dan menghargai pendapat orang lain. Tekun dan tidak mudah bosan, kaya akan inisiatif bersikap kritis terhadap permasalahan yang muncul, menggunakan waktu luang untuk kegiatan bermanfaat dan memiliki kesadaran etika dan moral yang tinggi.

Faktor utama yang mempengaruhi hasil belajar siswa adalah kreativitas guru. Sebab di lingkungan sekolah guru berperan untuk meningkatkan hasil belajar siswa. Guru harus selalu berusaha membangkitkan minat siswa sehingga seluruh perhatian mereka tertuju dan terpusat pada bahan pelajaran yang sedang diajarkan.

Perhatian yang dibangkitkan oleh seorang guru merupakan hal yang disengaja sedangkan dari diri siswa disebut perhatian spontan. Hasil perhatian spontan biasanya dapat berlangsung lama dan lebih baik dari pada perhatian disengaja. Jadi pembentukan watak sebagai proses pembelajaran di kelas di samping persiapan untuk terjun dalam masyarakat, perhatian disengaja lebih penting.

\section{HIPOTESIS STATISTIK}

Berdasarkan rumusan masalah, kajian teoritis dan paradigma berpikir dalam penelitian ini maka dikemukakan hipotesis penelitian sebagai berikut:

$\mathrm{H} 0: \beta \geq 0, \quad \begin{aligned} & \text { Kreativitas guru tidak } \\ & \text { berpengaruh positif }\end{aligned}$ 


\begin{tabular}{llr}
\hline & $\begin{array}{l}\text { terhadap hasil } \\
\text { siswa }\end{array}$ & belajar \\
$\mathrm{H}_{1}: \beta>0$, & Kreativitas & guru \\
& berpengaruh & positif \\
& terhadap hasil belajar \\
& siswa
\end{tabular}

\section{METODE PENELITIAN}

Berdasarkan permasalahan yang telah dikemukakan sebelumnya, maka yang menjadi objek dalam penulisan yaitu siswa kelas X SMA Negeri 1 Moutong Kabupaten Parigi Moutong Provinsi Sulawesi Tengah. Pemilihan lokasi didasarkan atas beberapa pertimbangan yaitu:

1) Objek tersebut dapat memberikan keterangan lengkap tentang masalah yang diteliti

2) Data yang diperlukan cukup memadai

3) Lokasi tersebut mudah dijangkau sehingga dari segi waktu yang digunakan peneliti dalam penelitian ini adalah selama satu bulan

\section{VARIABEL PENELITIAN}

Variabel adalah objek penelitian atau apa yang menjadi titik perhatian suatu penelitian (Arikunto, 2002:96)

Variabel penelitian mmerupakan atribut-atribut yang mempengaruhi kreativitas guru terhadap hasil belajar siswa pada mata pelajaran ekonomi di SMA Negeri 1 Moutong Kabupaten Parigi Moutong Provinsi Sulawesi Tengah. Adapun variabel penelitian ini adalah sebagai berikut:

\section{Variabel Bebas (Variabel X)}

Variabel $X$ pada penelitian ini adalah bertolak dari teori Parnes yaitu:
1) Fluency
2) Fleksibilitas
3) Originalitas
4) Elaboration
5) Sensitivity

\section{Variabel Terikat (Variabel Y)}

Variabel Y pada penelitian ini adalah hasil belajar siswa dengan indikator yaitu:

1) Pree Tes

2) Post Tes

\section{SAMPEL DAN TEKNIK SAMPLING}

Sampel adalah bagian dari populasi yang menjadi objek dalam penelitian. Menurut Arikunto (2002:112) bahwa: "apabila populasinya kurang dari 100 maka yang menjadi sampel adalah keseluruhan dari populasi tersebut atau disebut dengan sampel total, sedangkan apabila jumlah populasinya lebih dari 100 maka yang menjadi sampel adalah $10 \%-15 \%$ atau 20\%$25 \%$ atau lebih. Yang menjadi sampel dalam penelitian ini adalah $25 \%$ dari jumlah total populasi yang berjumlah 122 siswa yakni 30 siswa.

Berdasarkan populasi dan sampel di atas, maka teknik pengambilan sampel yang digunakan dalam penelitian ini adalah teknik stratified random sampling. Teknik ini dimaksudkan bahwa sampel dari populasi yang ada secara acak atau mewakili dari keseluruhan populasi yang ada.

\section{INSTRUMEN DAN TEKNIK PENGUMPULAN DATA}

Menurut Arikunto (2010:192) instrument adalah alat untuk memperoleh data pada waktu penelitian dengan menggunakan suatu 
metode. Dalam penelitian ini data yang dikumpulkan melalui instrumen berupa angket dengan jumlah butir soal nomor, dimana tiap variabel terdiri atas:

a. Variabel $X$ terdiri atas 15 item soal dengan menggunakan 5 option

b. Variabel $Y$ terdiri atas 15 item soal dengan menggunakan 5 option.

Kuisioner ini terdiri dari pernyataan-pernayataan yang disertai dengan jawaban-jawaban dalam bentuk skala yang dikembangkan oleh Rensis Likert ini biasanya memiliki 5 atau 7 kategori peringkat dari sangat tidak setuju hingga sangat setuju. Jadi untuk masing-masing telah dilengkapi dengan pilihan alternatif jawaban yang dikehendakinya sesuai dengan petunjuk yang ada. Selanjutnya dimana alternatif jawaban untuk setiap intern soal terdiri dari a, b, c, d dan e. Untuk setiap intern soal yang menghendaki jawaban positif, maka skor jawaban dimulai dari angka skor $5,4,3,2$, dan 1 sedangkan yang menghendaki jawaban yang negatif dimulai dari angka 1, 2, 3, 4 dan 5 . Penentuan instrumen butir pertanyaan pada angket mengacu pada indikatorindikator seperti kisi-kisi.

\section{TEKNIK ANALISIS DATA}

Dalam pengujian hipotesis, maka langkah pertama adalah menguji normalitas data dimaksudkan untuk mengetahui apakah data hasil penelitian berasal dari populasi yang berdistribusi normal atau tidak. Untuk itu digunakan uji statistik dengan menggunakan chi-kuadrat sebagai berikut:

$$
X^{2}=\sum \frac{\left.O_{i}-E_{i}\right)^{2}}{E_{i}} \quad \text { (Yunus, 2007:109) }
$$

Dengan kriteria pengujian sebagai berikut:

a. Uji linieritas

Terima hipotesis persamaan regresi linier, jika $\mathrm{F} \leq \mathrm{F}_{(1-\alpha)(1, n-2)}$ dengan taraf nyata $(\alpha)=0,1$

b. Uji keberartian

Terima hipotesis persamaan regresi linier berarti, jika $F \geq F_{(1-\alpha)(1, n-2)}$ dengan taraf nyata $(\alpha)=0,1$

c. Koefesien korelasi

$$
\begin{aligned}
& \mathrm{r}=\frac{N \sum X Y-\sum X \sum Y}{\sqrt{\left\{N\left(\sum X^{2}\right)-\left(\sum Y\right)^{2}\right\}\left\{N\left(\sum Y^{2}\right)-\left(\sum Y\right)^{2}\right\}}} \\
& \text { (Yunus 2007:145) }
\end{aligned}
$$

\section{HASIL PENELITIAN}

\section{Pengujian Persyaratan Analisis}

Untuk kepentingan pengujian normalitas data digunakan uji chikuadrat $\left(\mathrm{X}^{2}\right)$. pengujian ini dilakukan terhadap skor variabel $\mathrm{X}$ (kreativitas guru) dan skor data Variabel Y (hasil belajar siswa).

Uji Normalitas Variabel $\mathrm{X}$ (kreativitas guru) menunjukkan harga $\mathrm{X}^{2}$ hitung $=31,74$, sedangkan dari daftar distribusi frekuensi diperoleh harga $\quad \mathrm{X}_{\text {daftar }}{ }_{(0,95(3)}=7,81$. Dengan demikian dapat dikatakan

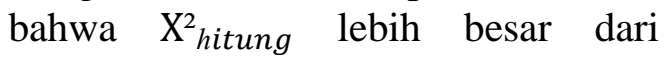
$\mathrm{X}^{2}$ daftar. Hal ini menunjukkan atau berarti bahwa data hasil penelitian untuk variabel $\mathrm{X}$ berasal dari populasi berdistribusi tidak normal (hasil perhitungan terlampir).

\section{PENGUJIAN HIPOTESIS}

Untuk pengujian hipotesis dalam penelitian ini, terlebih dahulu perlu diadakan pengujian-pengujian sebagai berikut: regresi, linieritas, keberartian, 
persamaan regresi dan koefisien korelasi serta menguji keberartian koorelasi.

1) Mencari persamaan regresi Untuk mencari persamaan regresi digunakan rumus $\hat{Y}=a+b x$ sehingga dari hasil perhitungan (terlampir) diperoleh persamaan regresi sebagai berikut; $Y=0.046698+0.887972 x$. hal ini berarti bahwa setiap terjadi perubahan sebesar satu unit pada variabel $\mathrm{X}$, maka akan diikuti oleh perubahan rata-rata variabel $\mathrm{Y}$ sebesar 0.887972x $x$ unit.

2) Uji koefisien regresi (uji t)

Hasil pengujian linieritas dan keberartian persamaan korelasi (perhitungan terlampir).

Untuk pengujian koefisein regresi diperooleh $t_{\text {hitung }}=3.699459$ dan dari daftar distribusi frekuensi diperoleh harga $t_{\text {daftar }}=2.05$. dengan demikian bahwa uji koefisien regresi yang telah dilakukan (terlampir) dapat diterima atau berarti. Hal ini berarti bahwa baik untuk uji linieritas persamaan regresi maupun untuk uji keberartian persamaan regresi data hasil penelitian benar-benar linier dan berarti. Artinya bahwa persamaan regresi yang telah diperleh telah memenuhi kriteria untuk dipergunakan dalam melakukan prediksi (ramalan) perubahan yang terjadi pada variabel dependen (hasil belajar siswa) bila nilai dalam variabel independen (kreativitas guru) terjadi perubahan.

3) Menghitung koefisien korelasi

Berdasarkan hasil perhitungan (terlampir) untuk uji koefisien korelasi diperoleh harga $\mathrm{r}=0.5724$ dan $\mathrm{r}^{2}=0.32773$ atau $32.773 \%$. Hal ini berarti bahwa sebesar $32.773 \%$ variasi yang terjadi pada hasil belajar siswa dapat dijelaskan oleh kreativitas guru yang ada di SMA Negeri 1 Moutong.

\section{PEMBAHASAN}

Berdasarkan hasil pengujian hipotesis yang telah dilakukan dan dibuktikan, maka dikatakan bahwa hipotesis penelitian dapat diterima. Hal ini menunjukkan bahwa kreativitas guru mempunyai hubungan positif terhadap hasil belajar siswa di SMA Negeri 1 Moutong Kabupaten Parigi Moutong Provinsi Sulawesi Tengah. Oleh karena itu kreativitas guru ini perlu dikembangkan dengan lebih baik dan tepat oleh guru, karena hal ini dapat mempengaruhi hasil belajar siswa di SMA Negeri 1 Moutong.

Sebagimana yang telah diuraikan di atas, dikatakan bahwa kreativitas guru yang baik dan tepat pada dasarnya dapat meningkatkan hasil belajar siswa pada SMA Negeri 1 Moutong. Dari hasil penelitian diketahui bahwa pengaruh yang ditimbulkan oleh kreativitas guru terhadap hasil belajar siswa cukup besar, yaitu $32.773 \%$. dari hasil tesebut menunjukkan bahwa setiap terjadi penurunan hasil belajar siswa SMA Negeri 1 Moutong selain faktorfaktor lainnya, guru perlu menelaah kembali kreativitasnya dalam mengajar. Apabila dilakukan analisa terhadap penyebab terjadinya penurunan hasil belajar siswa dapat dipastikan bahwa $32.773 \%$ disebabkan oleh menurunya kreativitas guru. Demikian pula sebaliknya ketika 
terjadi peningkatan hasil belajar siswa maka sebesar itu pula disebabkan oleh peningkatan prestasi belajar siswa dalam belajar.

Salah satu faktor yang mempengaruhi hasil belajar siswa baik secara langsung maupun tidak langsung adalah guru. Peranan guru dalam kegiatan pembelajaran amat dominan, oleh karena itu guru hendaknya mampu mengembangkan diri seiring dengan lajunya perkembangan ilmu pengetahuan dan teknologi. Konsekuensi logis dari semua ini adalah bahwa guru harus berupaya untuk selalu kreatif dalam kegiatan pembelajaran. Kreativitas guru ini dapat diwujudkan melalui kemampuan guru dalam menyelesaikan suatu masalah, bersifat terbuka terhadap siswa, semangat dalam proses pembelajaran, dan memberikan motivasi belajar kepada siswa serta merespon dengan baik bagi siswa dalam konsultasi untuk menemukan kesulitan dalam belajar.

Dalam pengujian koefisien regresi (uji t) dapat diperoleh $t_{\text {hitung }}=3.69$ sedangkan untuk $t_{\text {daftar }}=2.05$ ternyata harga $t_{\text {hitung }}$ lebih besar dari $t_{\text {daftar }}$. Hal ini berarti bahwa kreativitas guru sangat berpengaruh terhadap hasi belajar siswa di SMA Negeri 1 Moutong Kabupaten Parigi Moutong yaitu semakin baik kreativitas guru dalam memberikan pembelajaran kepada siswa maka semakin meningkat pula hasil belajar siswa terhadap pembelajaran tersebut.

\section{SIMPULAN}

Berdasarkan deskripsi hasil penelitian dan pembahasan yang telah dikemukakan sebelumnya, maka peneliti dapat menarik kesimpulan sebagai berikut:

1. Terdapat pengaruh yang signifikan antara kreativitas guru terhadap hasil belajar siswa terbukti kebenarannya. Hal ini dibuktikan melalui uji koefisien regresi ((uji t), dimana harga $t_{\text {hitung }}=3.694$ $t_{\text {tabel }}=2.05$, dengan demikian $t_{\text {hitung }}>t_{\text {daftar }}$ sehingga Ho ditolak dan menerima Ha.

2. Kreativitas guru dalam pembelajaran akan meningkatkan hasil belajar siswa, hal ini dapat dilihat dari hasil pengujian hipotesis dimana hasil belajar siswa dipengaruhi oleh kreativitas guru sebesar 0.32773 atau $32.773 \%$

3. Dalam mencapai hasil belajar yang maksimal perlu adanya dukungan subsistem pembelajaran yang meliputi beberapa komponen, yaitu materi dan bahan, metode strategi dan pendekatan, sarana dan prasarana, biaya dan kurikulum, yang semua komponen tersebut dapat membantu guru dalam mengembangkan efektifitas mengajarnya khususnya pada mata pelajaran ekonomi.

\section{DAFTAR PUSTAKA}

Anik, Pamilu. 2007. Mengembangkan Kreativitas dan Kecerdasan Anak. Yogyakarta: Citra Media.

Aunurrahman. 2010. Belajar dan Pembelajaran. Bandung: Alfabeta.

Dimyati. 2006. Belajar dan Pembelajaran. Jakarta: Rineka Cipta.

Mulyasa, E. 2007. Menjadi Guru Profesional (Menciptakan Pembelajaran Kreatif dan 
Menyenangkan). Bandung:

Rineka Cipta.

2009. Implementasi

Kurikulum Tingkat Satuan

Pendidikan (kemandirian guru

dan kepala sekolah). Jakarta:

Bumi Aksara.

Nana, Sudjana. 2008. Penelitian Hasil

Proses Belajar Mengajar.

Bandung: Remaja Rosda Karya.

Nursisto. 1999. Kiat Menggali

Kreativitas. Yogyakarta: Mitra

Gama Widya.

Sugiono. 2009. Metode Penelitian

Kuantitatif dan $R \quad \& \quad D$.

Bandung: Alfabeta.

Uno. B. Hamzah. 2007. Profesi

Kependidikan (Problema,

Solusi, dan Reformasi

Pendidikan di Indonesia).

Jakarta: Bumi Aksara.

Usman, Moh. Uzer. 2006. Menjadi

Guru Profesional. Bandung:

Remaja Rosda Karya.

Utami, S. C. Munandar. 1992.

Mengembangkan Bakat dan

Kreativitas Anak Sekolah.

Jakarta: Gramedia Widisarana Indonesia.

Yunus, Hamzah. 2007. Statistik Ekonomi. Gorontalo: Universitas Negeri Gorontalo. 